\title{
ESTRATEGIAS DE URBANIZACIONES COSTERAS DE LOCALIDADES BALNEARIAS, ARGENTINA
}

\section{COASTAL URBANIZATION STRATEGIES FOR RESORT LOCATIONS, ARGENTINA}

Federico Ignacio Isla*

María del Pilar Isla**

ABSTRACT: Coastal cities have particular spatial urbanization trends conditioned by the dominant activities, meaning tourism, fishing or commerce. Notwithstanding that, there are other issues or restrictions that also conditioned the growing pattern of these villages or cities that can change during their development. In this sense, monocentric patterns (harbor cities) may evolve into a radial model related to main accessing routes. Touristic cities emplaced on barrier systems extended alongshore while their service areas installed at opposite directions where lots are cheaper. Some coastal villages grew exponentially in the last century in Argentina although they had original restrictions in the freshwater availability. Today, they are also conditioned to the recreational qualities of their beaches, or the disposal availability of residential sewages.

Key words: Urban growth, coastal cities, Buenos Aires, Patagonia, Argentina

RESUMEN: Las ciudades costeras tienen particulares tendencias de urbanización condicionadas por las actividades dominantes, e.g. turismo, pesca o comercio. A pesar de ello, existen otros temas o restricciones que también condicionan los patrones de crecimiento de villas o ciudades que pueden cambiar durante su desarrollo. En ese sentido, diseños monocéntricos (ciudades puertos) pueden evolucionar a modelos radiales relacionados a las principales vías de acceso. Ciudades turísticas emplazadas en sistemas de barreras se extienden a lo largo de la costa mientras sus áreas de servicios se instalan en sectores opuestos donde los lotes son más baratos. Algunas villas costeras de Argentinacrecieron exponencialmente en el último siglo a pesar de restricciones originales de disponibilidad de agua potable. Hoy, están también condicionadas a la calidad recreacional de sus playas, o a la capacidad de los desechos cloacales de las residencias.

Palabras clave: Crecimiento urbano, ciudades costeras, Buenos Aires, Patagonia, Argentina

Recibido: 17.03.19 Aceptado: 29.11.19

* Instituto de Geologia de Costas y del Cuaternario (UNMDP-CIC) - Instituto de Investigaciones Marinas y Costeras (UNMDP-

CONICET), Funes 3350, Mar del Plata, Argentina. fisla@mdp.edu.ar https:orcid.org/0000-0002-4930-0907

** Facultad de Arquitectura, Urbanismo y Diseño, UNMDP, Funes 3350, Mar del Plata, Argentina.

mariadelpilarsila@gmail.com 


\section{INTRODUCTION}

Beach resorts originated as far as the XVIII century in response to a demand for medical purposes. Most of these resort villages of Wales, England and France are today coastal cities where their origins are fairly remembered, although they are still seasonally crowded by low-class visitors. Notwithstanding that coastal cities are critical areas of environmental change, they were not usually subject to analyses of coastal zone management or urban planning (Timmerman and White, 1997). However, some authors paid attention to the "Geography of the resort growth" which involves two initial stages: the pioneer resorts, and the clone-like resorts (Shaw and Agarwal, 2007).

In 2004, there were more than 400 cities with more than a million residents; about three quarters in low- and middle-income countries (Cohen, 2004). At the same time, considering the 25 largest cities lover 9 million inhabitants) in the year 2000, 17 were at the coast. Population living in coastal cities and agglomerations is 7 times more abundant than in the XX century (Barragán and De Andrés, 2015). Approximately 2.8 billion people live closer than $100 \mathrm{~km}$ from the coast. Regarding the urban growth of mid-sized cities from different geographical settings and economic levels, four types were discriminated:

a) Low-growth cities, with modest rates of expansion,

b) High-growth cities, with rapid and fragmented development,

c) Expansive-growth urbanizations, for extensive dispersion at low densities, and d) Frantic-growth cities, for the Chinese type of extraordinary growth rates at high population densities (Schneider and Woodcock, 2008).
Coastal cities have special patterns of urban expansion although their advantages are usually spoiled by their rapid growth without planning. They progressively increased their demands of water, materials and energy supplies. The "water infrastructure" means the management of freshwater supply and wastewater treatment (Timmerman and White, 1997). The rapid growth also induces specific higher vulnerability to natural risks (Su et al., 2015). Usually, the early symbiosis between the coastal ecosystem and the urban ecosystem becomes dysfunctional as the city expands (Yeung, 2001). Some of these issues concerning the growing of coastal mega-cities have been discussed in 1999 and specified on the Hangzhou Declaration (Li, 2003).

Cities have different specific determinants: economic, social, physical or public interests that explain land use patterns (Baver, 2010). Urban growth models can be classified into monocentric, axial or polycentric. Big cities, as Mexico or Madrid, grew from a monocentric model. Other cities with alternative resources have a polycentric model like the ConcepciónTalcahuano complex, Chile (Rojas et al., 20131.

Some cities have grown in a transition from a port to a monocentric scheme. Touristic cities expand alongshore in response to the minimum distance to beaches. Cities that grew on temperate dune barriers were restricted to the width of those barriers that content fresh water in their sand bodies. Cities on deltaic plains were originally focused to water-consuming crops (as rice). Today, most of them are at risks of storm surges or long-term sea level rise. Their vulnerability should be analyzed either in terms of the risk frequency but also in their adaptive capacity (Su et al., 2015). 


\section{BACKGROUND}

The original coastal population of Argentina grew in relation to the particular needs of Buenos Aires inhabitants. The Patagonia region was occupied since 1752 only for the seasonal mining of salt to be consumed in Buenos Aires (lsla, 2002). In 1778 Carmen de Patagones was the natural harbor at the inlet of the Negro River for the commerce with Northern Patagonia (Fig. 1). The availability of fresh water determined the success or failure of some of the old Patagonian harbors (Puerto Deseado, Puerto San Julián, Puerto Santa Cruz; Rio Gallegos; Isla, 2002).
To the end of the XIX century, some touristic cities as Mar del Plata, Miramar or Quequén have grown in relation to the European fashion demanding baths at the sea (Fig. 2). In Mar del Plata, the original conflict between the visiting tourists and the local fishermen using the same bay (Bahía of the Bristol Hotell was solved favoring the bathers and promising the construction of a fishing harbor. During the second half of the XX century, the access of the middle social classes to summer holydays and to second houses initiated the growing of new touristic areas at Pinamar, Villa Gesell, Mar de Ajó, San Bernardo, and San Clemente del Tuyú (Isla, 2013).

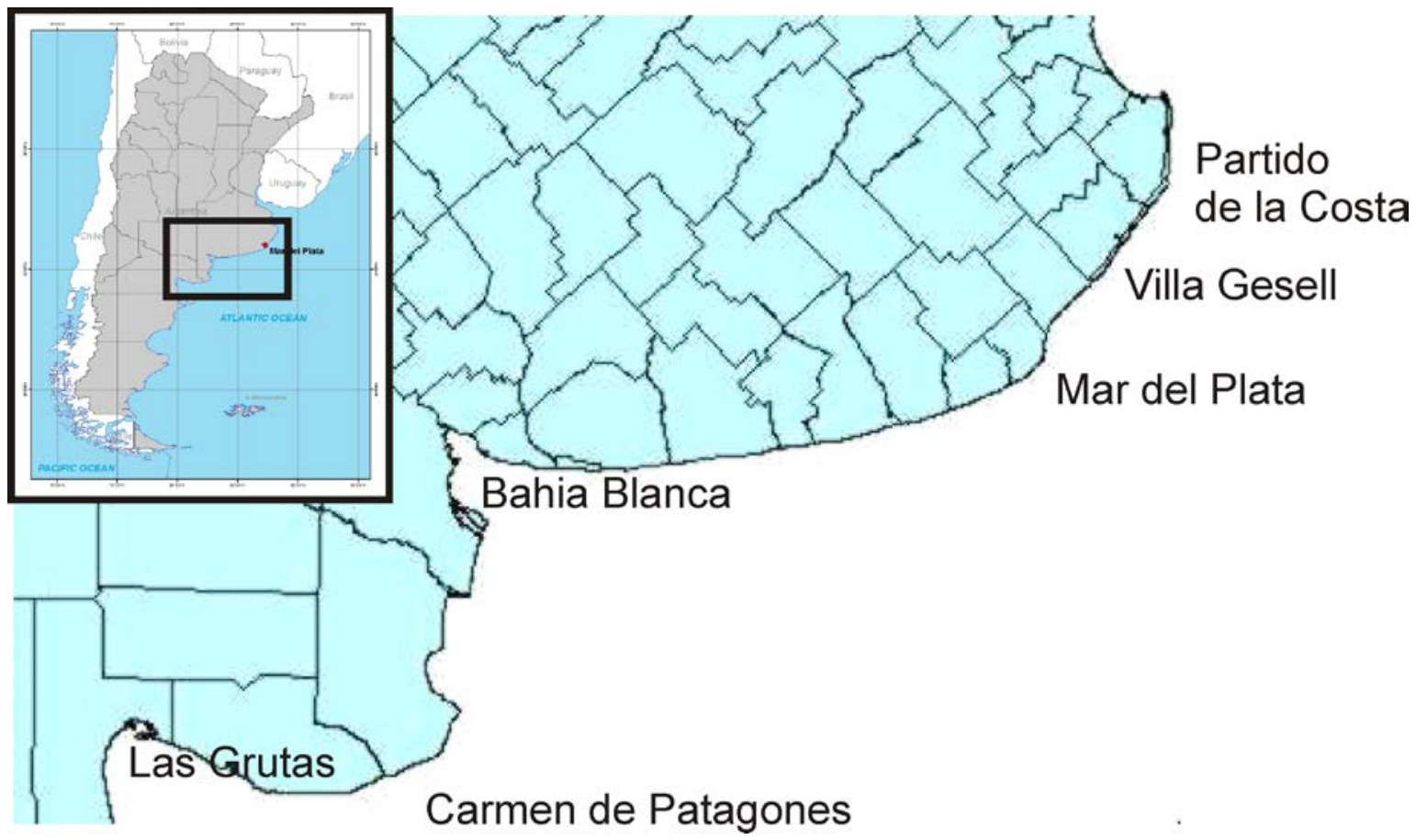

Figure 1: Location of the cities and touristic villages analyzed (Elaboración propia). 


\section{METHODS}

TM satellite images (30 m spatial resolution) were processed in order to get false-color composite images /green, red and NIR; $5 \%$ lineal saturation). Old images from 1986 were compared to modern ones (2011). Land-use areas were estimated for Mar del Plata and Villa Gesell cities (Fig. 2) using the minimum-distance method of supervised classification (Eastman, 2006). For Mar del Plata, 8 land uses were discriminated:
a) ocean,
b) sand, quarries and breaker zone (sea foam),
c) shallow lakes,
d) agriculture,
e) urban areas,
f) residential,
g) residential-forested, and
h) forested areas.

In Villa Gesell, with a different urbanization scheme on a different environmental setting on a sand barrier, 7 training sites were recognized:
a) ocean,
b) sand,
c) shallow lakes,
d) grasses,
e) urban areas,
f) forested areas, and
g) marshes.

Land-use maps from both cities were compared (1986-2011) using the procedure techniques of the Land Change Modeler (LCM; Eastman, 2006). In Mar del Plata, with a radial urban expansion, main routes $(2,11,88$ and 226) were digitized. Land-use transitions of less than 500 hectares were discarded.

\section{RESULTS}

\section{A. FRESHWATER-RESTRICTED RESORT VILLAGES}

Dune barriers are accumulations of sand that comprise several benefits for residential buildings: beach proximity, freshwater availability and a soft ground for funding and piping. Their growths are usually linear along the coastline. Prices of the lots diminish as the distance to the beach increases. These villages are restricted in their growing rates as they must pump water from elongated lens within the sand-barrier body, and therefore the water availability is restricted depending mostly of the widths and thicknesses of these lenses (Carretero et al., 2014). Along the Partido de la Costa (Fig. 2) there are good examples of these water-restricted cities and/or villages limited to the west by beach ridges immerse in a brackish-water dominated plain (Fig. 2).

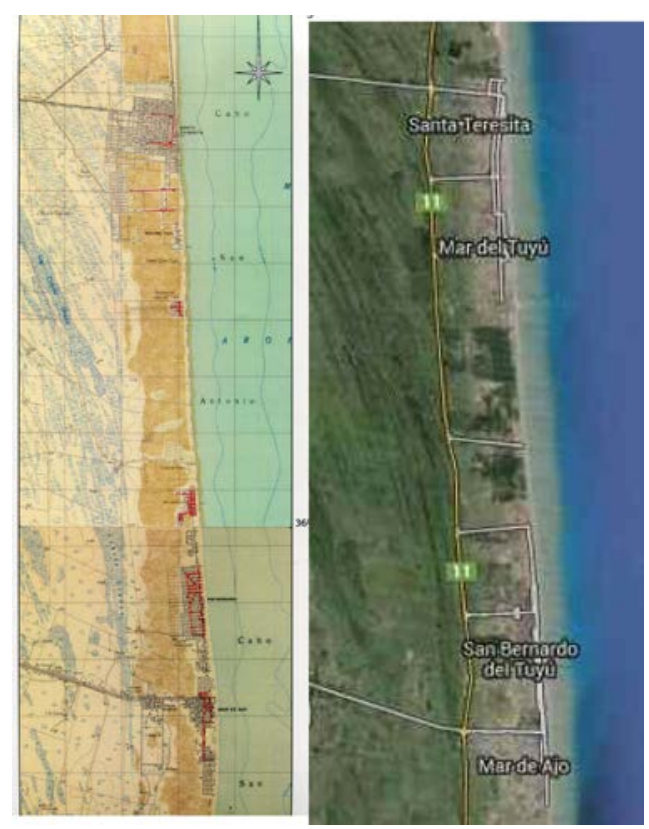

Figure 2: Alongshore growing of the resort villages of Partido de la Costa. A) Topographic map performed during the sixties (source Instituto Geográfico Nacional of Argentina). B) Satellite image from October 23, 2005 (source Google Earth). 


\section{B.BARRIER CITIES WITH DOWNTOWNS}

Where the widths and altitudes of these barriers are not restrictive, there are enough supplies of fresh water that can fulfill the requirements for cities that increase significantly their population during the summer months. Cities as Villa Gesell and Pinamar (Fig. 1) are also growing alongshore, but there is a downtown concentration in a monocentric way. Some restrictions can limit their expansion when resort villages became populated cities. During many years, Villa Gesell and Pinamar sent their domestic waste water towards shallow ponds with a minor treatment IIsla, 2013). In the last years, the odors at the end of the season at these "sacrifice ponds" made the decision makers to think about an alternative waste-water treatment policy.

In Villa Gesell, the original growth alongshore became across-shore, as the city increased its services towards the continent, but always funding over the sandy barrier to assure the water supply and funding facilities. However, considering the more extended transitions, the changes from a sandy soil to urban buildings were higher than 600 hectares in 25 years. In the last years, real-state rules were proposed to restrict buildings heights close to the beach (Municipalidad de Villa GesellUNLP, 2002). Other cities have already established setbacks with restrictions in altitude of the buildings.

\section{C.HARBOR CITIES: FROM A MONOCENTRIC TO A RADIAL PATTERN}

Those cities originated in relation to harbor activities grow away in a monocentric mode from the main land use. Within this mode, commercial activities concentrate along the main avenues. Progressively, these activities increase in such a way that the pattern becomes axial. The city of Mar del Plata grew in relation to a seasonal tourism but also in response to the fishing harbor. Today, the growing of the city has a radial behavior concentrated along the routes 2 , 11,226 and 88 (Fig. 3).

A
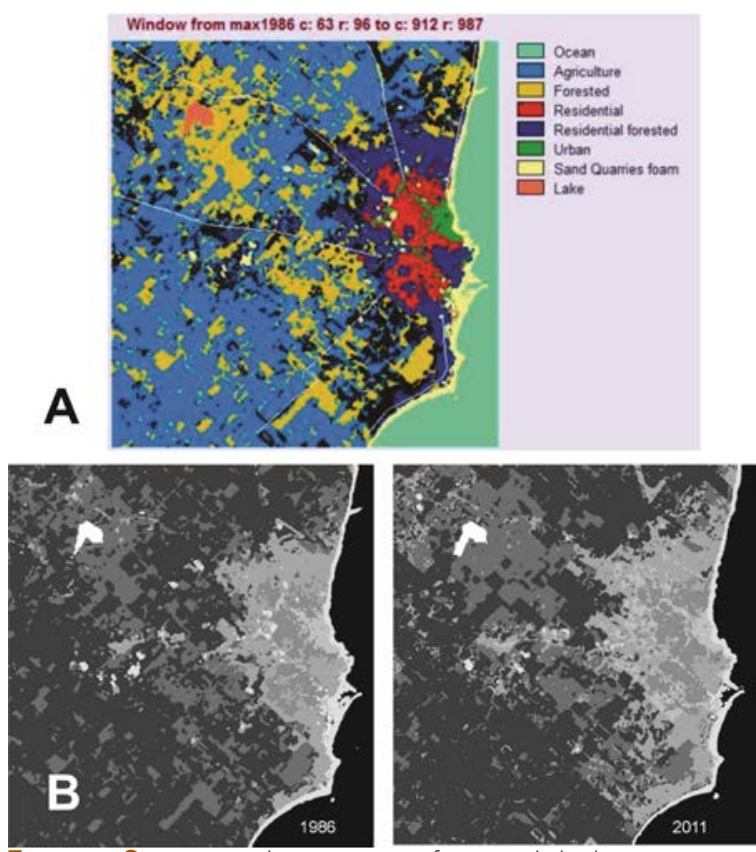

Figure 3. a) Land-use map of Mar del Plata city with main accessing routes. b) Mar del Plata grew from a monocentric pattern in 1986 to a radial pattern in 2011 (modified from Leveau 2014).

In Mar del Plata, the more common transitions are between forested to agriculture, and viceversa (more than 5000 hectares in 25 years). Considering changes of more than 1000 hectares, there were transitions from agriculture to residential-forested, forested to residential-forested, and residential-forested to urban areas. During the last 25 years Mar del Plata expanded following a radial model concentrated along the main routes: 2 (Mar del Plata-Buenos Aires), 11 (Mar del Plata-Miramar, and Mar del Plata-Santa Clara), 88 (Mar del Plata-Necochea), and 226 (Mar del Plata-Balcarce). This radial pattern was also reported in relation to the socioeconomic and environmental-quality indexes. 


\section{VILLAGES ON CLIFF-TOP DUNES}

Not all the dune barriers are built on lowlying plains. Conditioned to the availability of sand, dunes climbed on top of sea cliffs. The villages constructed on top of these barriers have certain benefits for urbanization (beach proximity, low flooding risks). However, water availability is also restricted to the size of the dunes, and their capacity to receive waste water is very restricted (Isla et al., 2018).

The village of Las Grutas at San Matías Gulf, Rio Negro Province (Fig. 1), grew in response to a beach characterized by warm and clear water, ideal for bathing and diving. However, this resort village is located on a semiarid region where water is provided by a $150 \mathrm{~km}$ long channel from the Negro River (Pomona-San Antonio Oeste channell. As fresh water was not still a restriction, house and building constructions became a boom during the eighties. However, the derivation of the waste water was not foreseen as a new restriction. The wastes derived to sink holes saturated the aquifers to the end of the summer. As the cliffs are composed partially of indurated clays (Patagonia Formation), with several planes of alternating lithology properties, the waste water seeps towards the sea cliffs, and finally to the beach. To the end of the summer (February), the percolation of such a quantity of sink holes signifies odors at the base of the cliffs (backshore) crowded of tourists.

\section{E. INTEGRATED COASTAL MANAGEMENT}

The main obstacle to urban planning is the lack of a coastal management-oriented legislation in Argentina and its provinces. Coastal municipalities have their own expansion plans without a minimum knowledge about the plans of their neighbor counties. National and Federal authorities fail to stablish a minimum coordination. Several new villages are being planned without a formal agreement with the Federal (Province) agencies. Investors assume that water would be supplied lately although the resources are short and there is no plan of improvements. The seasonal peaks for water demands occur simultaneously for summer crops and maximum tourism consumption (Timmerman and White, 1997). For the Partido de la Costa district, the water consumption in 1973 that was $3 \%$ of the recharge to the aquifers, increased to $21 \%$ in 2010, and it is forecasted to be of the same order of magnitude to the recharge for the year 2050 (Carretero et al., 20 14). Groundwater demands should be consider for urban planners, specifically when dealing with sand barrier systems IIsla et al., 2018).

But this strategy of governments to manage each sector separately by different agencies (Tibbetts, 2002) is not only conceived to urban planning. For instance, a natural reserve (Arroyo Zabala, Buenos Aires) was proposed for the preservation of a wetland as ecological niches for birds under extinction risk (Chloephaga rubidiceps). At the same time, another agency in charge of the water administration was dredging the coastal barrier in order to drain that wetland.

In a similar way, Mar del Plata was improving the pluvial network towards a beach while the coastal engineers were restricting the outlet of that beach constructing "T" groynes (La Perla beach). It is a common policy to recover more beaches with less sanitary conditions derived from pluvial facilities IIsla et al., 2018).

The policies concerned to coastal administration can change between those that give priorities to the public ownership 
and those oriented to private investments. In Mar del Plata city, the Saint James Bay was deteriorated during the sixties /Figure 4a). An expropriation plan induced the destruction of several old hotels (Saint James, Bella Vista, Scafidi, Centenario) during the seventies. The elongation and construction of two jetties changed the coarse-grained reflective beach into a fine-sand pocket beach between two long jetties (Figure 4b). This artificial beach (Varese Beach) today receives more bathers although the sanitary conditions diminished.

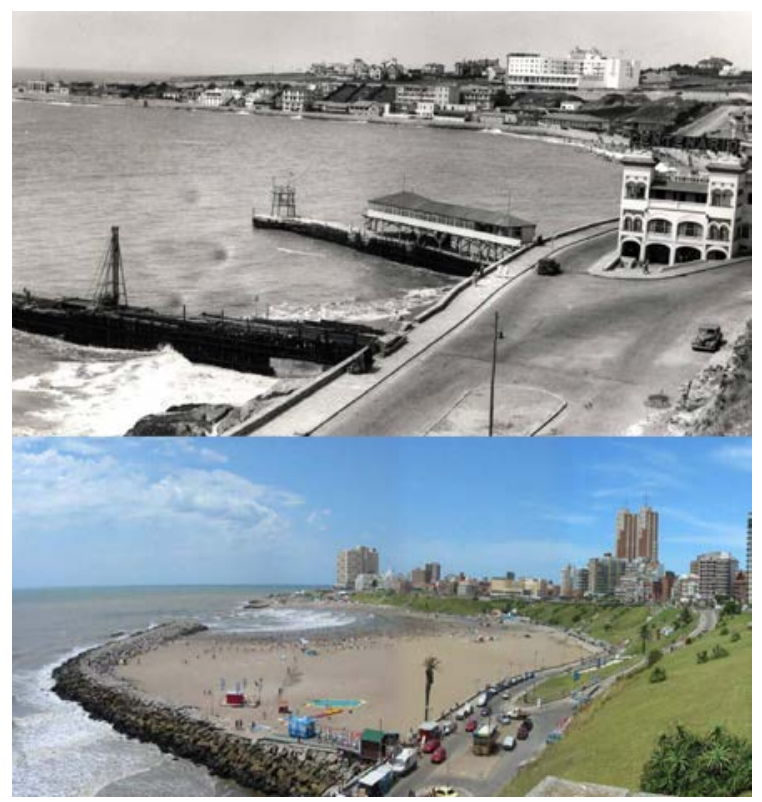

Figure 4. A. Playa de los Ingleses (formerly Saint James Bay) during the sixties. B. The same bay (Playa Varese) during the nineties after the destruction of the old hotels (From the author)
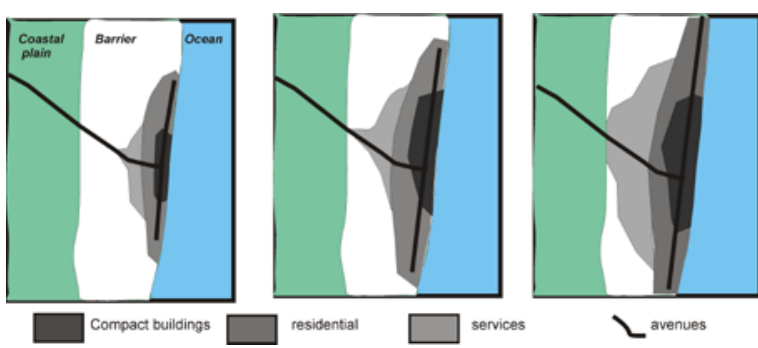

Figure 5. Idealized urban-sprawl model of a touristic village on a sand barrier (Elaboración propia).
The polycentric urban growth is unavoidable for coastal villages related to headlandbay beaches. This is the case of the resort villages of Santa Catarina State, Brazil (Bombas, Bombinhas, Porto Belo, Zimbros, Ingleses). Another touristic city from Santa Catarina, Balneário Camboriú grew $1000 \%$ of the multifamily housing in 22 years (1978-2000) while the singlefamily housing increases only $115 \%$ in the same period (Ferreira et al. 2009). Concepción Metropolitan Area (Chile) also has polycentric growth derived from several harbor conditioned by the coastal configuration. Some cities are growing as residential areas (Concepción, San Pedro de la Pazl while other as harbors (Talcahuano, San Vicente). Although a Municipal Urban Plan was implemented the conurbation signifies worse conditions due to the increase in land-use and-cover changes (Rojas et al., 2013).

Some coastal cities had an exponential growth due to specific improvements. For example, the international airport of Fortaleza (Brazil) signified an increase in sun-and-beach touristic passengers from 900,000 in 1990 to $5,000,000$ in the XXI century. The city changed from "cidade com porto" to "cidade com aeroporto" (Paula et al., 2015). However, the touristic promotion contributed to the planning of fragmented urban centers with special processes of socioeconomic segregations (Rufino, 2015).

Coastal touristic cities close to agricultural regions are conditioned by critic water demands when both activities were at their higher levels (Timmerman and White, 1997). Undeveloped coastal areas are easily managed in relation to the "do nothing" or "retreat and relocate" alternatives (Jolicoeur and $O^{\prime}$ Carroll, 2007). 
One of the main troubles for planners and managers is to predict the future behavior of rapidly retreating coasts in response to present easily-predicted processes (wave action, storm frequency) and those uncertainly forecasted: climate or sea-level changes. Simulations based on multiple criteria were suggested to apply in order to consider only sea-level rise effects or the increasing risks by summing also storm frequency responses (Hansen, 2010).

Some predictive models are based on historical rates but differing in the way to apply them: simple extrapolation, trend analysis, or process-response routines (Castedoetal., 201 5). However, there are other variables more difficult to envisage: rainfalls and geology differences are difficult to forecast. In a similar way, habitat fragmentation is another issue to consider for landscape architects and planners. In those cases, decadal-scale variations are recommended to handle in order to avoid interannual or seasonal partial conclusions (Brooks et al., 20121. Regarding urban growth, it was envisaged that globalization can bring economy benefits to several countries but also potential risks (Cohen, 2004).

Regarding main resources of each coastal city, several urbanization patterns can be achieved:

1. Harbor-cities grew in response to the proximity to the port; later in relation to their main avenues and highways

2. Resort villages grew alongshore according to the access to recreational areas; later they expand across the barrier as the city requires more services.

\section{REFERENCES}

Barragán, J.M., De Andrés, M. (2015). Analysis and trends of the World's coastal cities and agglomerations. Ocean and Coastal Management, 114, 11-20.

Baver, K.W (2010). City planning for civil engineers, environmental engineers and surveyors. CRC Press, Taylor and Francis, 489.

Brooks, S.M., Spencer, T., Boreham, S. (2012). Deriving mechanisms and thresholds for cliff retreat in soft-rock cliffs under changing climates: Rapidly retreating cliffs of the Suffolk coast, UK. Geomorphology, 153-154, 48-60.

Carretero, S., Braga, F., Kruse, E., Tosi, L. (2014). Temporal analysis of the changes in the sand-dune barrier in the Buenos Aires Province, Argentina, and their relationships with the water resources. Applied Geography, 54, 169-181.

Castedo, R., De La Vega, R., FernándezHernández, M., Paredes, C. (2015). Measurements of historical cliff-top changes and estimation of future trends using GIS data between Bridlingotn and HornseaHolderness coast (UK). Geomorphology, $230,146-160$

Cohen, B. (2004). Urban growth in developing countries: a review of current trends and a caution regarding existing forecasts. World development, 32, 23-51.

Eastman, J. R. (2006). IDRISI Andes: Guide to GIS and image processing. Clark Labs, Clark University, Worcester, USA, 328 p. 
Ferreira, J. C., Silva, L., Polette, M. (2009). The coastal artificialization process. Impacts and challenges for the sustainable management of the coastal cities of Santa Catarina (Brazil). Journal of Coastal Research, 56, 1209-1213.

Hansen, H.S. (2010). Modelling the future coastal zone urban development as implied by the IPCC SRES and assessing the impact from sea level rise. Landscape and Urban Planning, 98, 141-149.

Hidalgo, R., Arenas, F., Santana, D. (2016). ¿ ¿tópolis o distópolis?: Producción inmobiliaria y metropolización en el litoral central de Chile (1992-2012). Eure, 42, 2754.

Isla, F.I. (2002). Los exploradores de la Patagonia: de Magallanes a Fitz Roy. Universidad Nacional de Mar del Plata, Mar del Plata, 217.

Isla, F.I. (2013). From touristic villages to coastal cities: The costs of the big step in Buenos Aires. Ocean \& Coastal Management, 77, 59-65.

Isla, F.I., Cortizo, L.C., Merlotto, A., Bertola, G., Pontrelli, M., Finocchietti, C. (2018). Erosion in Buenos Aires province: Coastalmanagement policy revisited. Ocean and Coastal Management, 156, 107-1 16.

Isla, F.I., Quiroz, O.M., Cortizo, L.C. (2018). Groundwater characteristics within loessic deposits: the coastal springs of Los Acantilados, Mar del Plata, Argentina. Environ. Earth Sciences, 77(610), 10.

Jolicoeur, S., O'Carroll, S. (2007). Sandy barriers, climate change and long-term planning of strategic coastal infrastructures, Illes-de-la-Madeleine, Gulf of St. Lawrence (Québec, Canada). Landscape and Urban Planning, 81 , 287-298.
Li, H. (2003). Management of coastal mega-cities. A new challenge in the $21 \mathrm{st}$ century. Marine Policy, 27, 333-337.

Leveau, M. (2014). Los efectos de la vegetación en la distribución y dinámica poblacional de aves en gradientes urbano-rurales. Unpublied. Thesis, Mar del Plata, 89.

Municipalidad de Villa Gesell Universidad Nacional de La Plata (2002). Plan estratégico Villa Gesell. Villa Gesell, Buenos Aires, 77.

Paula, D.P., De Morais, J.O., Ferreira, O., Alveirinho Dias, J. (2015). De um simples Porto a uma cidade convertida para o turismo. Artificialiçao do litoral de Fortaleza-CE, Brasil. O homem e a zonas costeiras (Pereira, S.D., Rodríguez, M.A.C., Bergamschi, S., Freitas, J.G., eds.l, Rio de Janeiro, 201-213.

Piazza, A.P., Amaral de Figueiredo, S., Calliari, L.J., Siqueira E., Marques, W., Beloti, T., Oleinik, P.H., Cardoso, R., Arigony, J., Cabral, Ch. (2019). Quantifying the geomorphologic and urbanization influence on coastal retreat under sea level rise. Estuarine, Coastal and Shelf Science, 230, 11.

Rojas, C., Pino, J. Basnou, C., Vivanco, M (2013) Assessing land-use and -cover changes in relation to geographic factors and urban planning in the metropolitan area of Concepción (Chile). Implications for biodiversity conservation. Applied Geography, 39, 93-103.

Rufino, M.B (2015). O. imobiliário como frente de expansão da metrópole: contradições na produção do espaço do Porto das Dunas. Eure, 41, 69-90. 
Schneider A., Woodcock, C.E. (2008). Timmerman, P., White R. (1997). Compact, dispersed, fragmented, Megahydropolis: coastal cities in the extensive? A comparison of urban growth context of global environmental change. on twenty-five global cities using remotely Global Environmental Change, 7, 205sensed data, pattern metrics and census 234.

information. Urban studies, 145, 659-692.

Shaw, G., Agarwal, S. (2007). urbana o desarrollo compacto? Estado de Introduction: The development and situación de una ciudad intermedia: Bahía management of coastal resorts: A global Blanca, Argentina. Revista Universitaria de perspective. Managing coastal tourism resorts (Agarwal, S., Shaw, G., eds). Chanel View Publications, 1-18. Geografía, 23, 97-124.

Verbeek, T., Boussauw, K., Pisman, A. (2014). Presence and trends of linear Su, S., Pi, J., Wan, Ch., Li, H., Xiao, R., Li, B (2015). Categorizing social vulnerability patterns in Chinese coastal cities. Ocean and Coastal Management, 1 16, 1-8.

Tibbetts, J. (2002). Coastal cities: Living on the edge. Environmental Health perspectives, $110,674-681$. sprawl: explaining ribbon development $\mathrm{n}$ the North of Belgium. Landscape and Urban Planning, 128, 48-59.

Yeung, Y. (2001). Coastal mega-cities in Asia: transformation, sustainability and management. Ocean and Coastal Management, 44, 31 9-333. 